\title{
Gastroenterostomy and vagotomy for chronic duodenal ulcer
}

\author{
A. W. DEllipiani, I. B. MACleOD ${ }^{1}$, J. W. W. THOMSON, AND A. A. SHIVAS \\ From the Departments of Therapeutics, Clinical Surgery, and Pathology, The University of Edinburgh
}

The number of operative procedures currently in vogue in the management of chronic duodenal ulcer indicates that none has yet achieved definitive status. Until recent years, partial gastrectomy was the favoured operation, but an increasing awareness of its significant operative mortality and its metabolic consequences, along with Dragstedt and Owen's demonstration of the effectiveness of vagotomy in reducing acid secretion (1943), has resulted in the widespread use of vagotomy and gastric drainage.

The success of duodenal ulcer surgery cannot be judged only on low stomal (or recurrent) ulceration rates; the other sequelae of gastric operations must be considered. Thus the metabolic consequences that may attend partial gastrectomy are now well recognized (Glaxo Symposium, 1967) and diarrhoea is known to be a frequent complication of vagotomy, though estimates of its incidence in a severe form vary (McKelvie, 1963; Burge, 1964; Cox and Bond, 1964). More complete studies after vagotomy have been infrequent, though Cox, Bond, Podmore, and Rose (1964) have contributed an important metabolic study of patients following vagotomy and gastroenterostomy.

The present communication reviews our results in patients who have undergone truncal vagotomy and gastroenterostomy for duodenal ulceration. A group of these patients has been subjected to more detailed metabolic studies.

\section{MATERIALS AND METHODS}

During the years 1957 to 1961,151 patients (112 males and 39 females) were submitted to gastroenterostomy and vagotomy for chronic duodenal ulceration. The operations were elective, and though a number of the patients had bled from their ulcers shortly before admission they were not bleeding at the time of surgery. One patient died postoperatively of a staphylococcal chest infection giving an operative mortality of $0.7 \%$.

The clinical status of these patients five to 10 years following surgery has been assessed. It was possible to interview 121 patients personally in hospital or at home, and 19 who lived overseas or elsewhere in the United ${ }^{1}$ Please address requests for reprints to I. B. Macleod, Department of Clinical Surgery, University Medical School, Teviot Place, Edinburgh 8.
Kingdom answered a postal questionnaire. Eight had died since operation, and three could not be traced. The patients were questioned particularly with regard to eating capacity, dumping symptoms, vomiting, ulcer-type dyspepsia, diarrhoea or other change in bowel habit, and a clinical assessment was made based on a modified Visick scale. The mean time since operation was 6.9 years.

Thirty-five patients from this group were admitted to hospital for a full investigation of gastrointestinal and related function two to seven years following their operation. Most were volunteers, but some were selected because of definite complaints. There were more females than males (21 females and 14 males). The following investigations were carried out on these patients:

ROUTINE HAEMATOLOGICAL INDICES (35 PATIENTS) Male patients with a haemoglobin level of less than $13.5 \mathrm{~g}$ per $100 \mathrm{ml}$, and females with a level of less than $11.5 \mathrm{~g}$ per $100 \mathrm{ml}$ were considered to be anaemic (Dacie and Lewis, 1963).

SERUM VITAMIN B $_{12}$ (35 PATIENTS) This was measured microbiologically using Lactobacillus leichmannii as the test organism (Girdwood, 1956, 1960)( normal range $=170$ to $1,000 \mu \mu \mathrm{g} / \mathrm{ml}$ ).

SERUM FOLATE (33 PATIENTS) This was measured microbiologically using Lactobacillus casei as the test organism (Kershaw and Girdwood, 1964; Girdwood, Williams, McManus, Dellipiani, Delamore, and Kershaw, 1966) (normal range $=2.2$ to $18.5 \mathrm{~m} \mu \mathrm{g} / \mathrm{ml}$ ).

VITAMIN B 12 ABSORPTION (35 PATIENTS) Measured by the Schilling test (1953), a urinary output of less than $7.5 \%$ of the orally administered dose of $0.5 \mu \mathrm{C}$ of ${ }^{58} \mathrm{Co}$-labelled vitamin in the subsequent 24 hours was considered to be abnormal. In some patients the test was repeated after five days of tetracycline therapy or with $50 \mathrm{mg}$ of intrinsic factor.

FIGLU TEST (35 PATIENTS) Formiminoglutamic acid was measured in the urine using conventional electrophoresis after a $15 \mathrm{~g}$ loading dose of histidine (Kohn, Mollin, and Rosenbach 1961; Kershaw and Girdwood, 1964).

FIVE-DAY FAECAL FAT EXCRETION (29 PATIENTS) The fat was measured by the method of van de Kamer, Huinink, ten Bokkel, and Weyers (1949). A faecal fat excretion of 
seven or more $\mathrm{g}$ per day was considered abnormal (Doig and Girdwood, 1960).

GASTRIC AND JEJUNAL MUCOSAL BIOPSY (GASTRIC 25 PATIENTS, JEJUNAL 24 PATIENTS) Biopsies were taken using the Crosby-Kugler capsule (1957) under fluoroscopic control. The gastric biopsies were assessed by observing variation in the total mucosal depth, the extent of lymphocytic and plasma cell infiltration, and loss of specialized cells from the deeper parts of the glands (intestinal metaplasia). They were consequently graded as showing 'mild', 'moderate', and 'severe' changes (Figs. 1 to 3). Jejunal biopsies were examined by dissection and by light microscopy. Our criteria for normality have been described elsewhere (Girdwood et al, 1966).

MAXIMAL HISTAMINE-STIMULATED GASTRIC SECRETION (32 PATIENTS) The test was carried out as described by Kay (1953), and the total secretion in the post-histamine hour determined.

INSULIN-STIMULATED GASTRIC SECRETION (35 PATIENTS) Twenty units of soluble insulin administered intravenously was used as the stimulant (Hollander, 1946), and an assessment of completeness of vagotomy was made on multiple criteria (Bank, Marks, and Louw, 1967).

SERUM IRON (35 PATIENTS) The method of Ramsay (1953) was used, and a level of less than $60 \mu \mathrm{g}$ per $100 \mathrm{ml}$ considered indicative of iron deficiency.

SERUM ELECTROLYTES, SERUM CALCIUM, PHOSPHORUS, AND ALKaline PHOSPHATASE Routine determinations were made.

ANTIBODIES TO PARIETAL CELLS AND INTRINSIC FACTOR (22 PATIENTS) Serum determinations of these autoantibodies were made using the method of Irvine (1966).

\section{RESULTS}

OVERALL CLINICAL ASSESSMENT OF PATIENTS FIVE OR MORE YEARS POSTOPERATIVELY Only $39 \%$ of patients were completely symptom free at this stage (Table I). In $11.4 \%$ of patients the operation was regarded as a failure (clinical grade IV) because of recurrent or stomal ulcer, severe dumping, diarrhoea, or vomiting.
TABLE I

OVERALL CLINICAL ASSESSMENT OF PATIENTS FIVE OR MORE YEARS POSTOPERATIVELY

\begin{tabular}{lcc}
$\begin{array}{l}\text { Clinical } \\
\text { Grade }^{1}\end{array}$ & $\begin{array}{l}\text { No. of } \\
\text { Patients }\end{array}$ & $\begin{array}{l}\text { Percentage } \\
\text { of Patients }\end{array}$ \\
\hline I & 55 & 39 \\
II & 36 & 26 \\
III & 33 & $23 \cdot 6$ \\
IV & 16 & $11 \cdot 4$ \\
Total & 140 & 100
\end{tabular}

\footnotetext{
$\mathbf{I}^{\mathbf{1}}=$ no symptoms

II = mild symptoms, no treatment required

III = moderate symptoms, requiring treatment

IV = severe symptoms, failures
}

Patients in clinical grades I and II (65\%) were regarded as having had a good result. Patients in grade III $(23.6 \%)$ were improved by operation and on the whole were pleased by the result: though handicapped to some degree by symptoms, they preferred these to their preoperative dyspepsia.

LONG-TERM SEQUELAE OF GASTROENTEROSTOMY AND VAGOTOMY The incidence of the major unpleasant sequelae in this series is given in Table II.

TABLE II

SEQUELAE OF ALL DEGREES OF SEVERITY IN 140 PATIENTS

\begin{tabular}{lcc} 
Symptom & $\begin{array}{l}\text { No. of } \\
\text { Patients }\end{array}$ & $\begin{array}{c}\text { Percentage } \\
\text { of Patients }\end{array}$ \\
\hline Dumping & 56 & 40 \\
Diarrhoea & 24 & 17 \\
Vomiting & 32 & 23 \\
Proven stomal ulcer & 6 & $4 \cdot 3$ \\
$\begin{array}{l}\text { Residual dyspepsia } \\
\text { (without proven stomal ulcer) }\end{array}$ & 15 & 11 \\
Hypoglycaemic attacks & 7 & 5
\end{tabular}

In many patients, these symptoms were of minor degree but their incidence in a form sufficiently severe to handicap normal activities was higher than we had anticipated: this is noted in Table III, which excludes the stomal ulcer patients.

It was possible to compare preoperative haemoglobin levels with haemoglobin levels at review in only 95 patients, and the results are indicated in Table IV.

TABLE III

\begin{tabular}{|c|c|c|c|}
\hline Symptom & $\begin{array}{l}\text { No. of } \\
\text { Patients }\end{array}$ & $\begin{array}{l}\text { Percentage } \\
\text { of Patients }\end{array}$ & Comments \\
\hline $\begin{array}{l}\text { Dumping } \\
\text { Diarrhoea } \\
\text { Vomiting }^{2}\end{array}$ & $\begin{array}{r}15 \\
7 \\
6\end{array}$ & $\begin{array}{r}10 \cdot 7 \\
5 \cdot 0 \\
4 \cdot 2\end{array}$ & $\begin{array}{l}\text { Weakness, flushing, sweating } \pm \text { vomiting or diarrhoea after main meals } \\
\text { Liquid stools. Episodes of diarrhoea lasting } 48 \mathrm{hr} \text { and occurring more than once a month } \\
\text { Vomiting occurring more frequently than once a month }\end{array}$ \\
\hline
\end{tabular}

1Two patients with very severe dumping had associated severe diarrhoea and are also included in the diarrhoea group.

${ }^{2}$ Vomiting usually bilious. Three patients required reoperation for this symptom. 


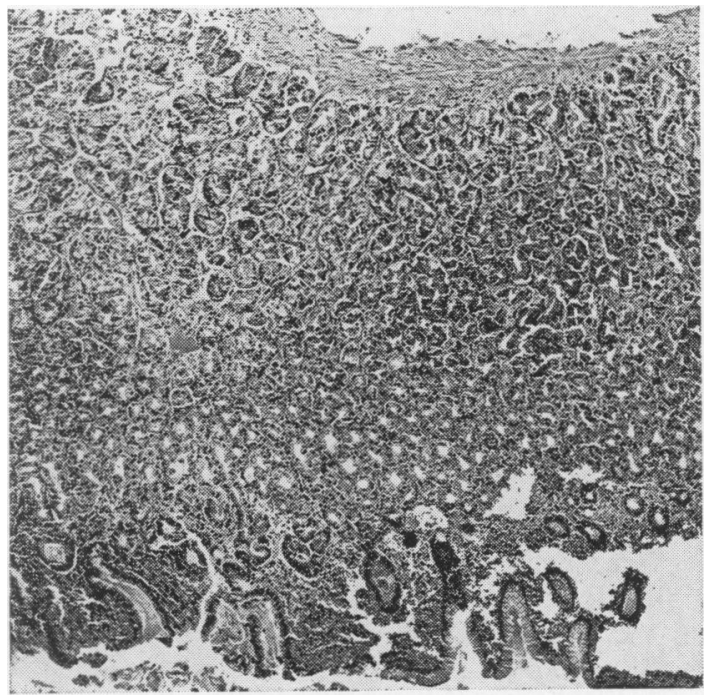

FIG. 1 .

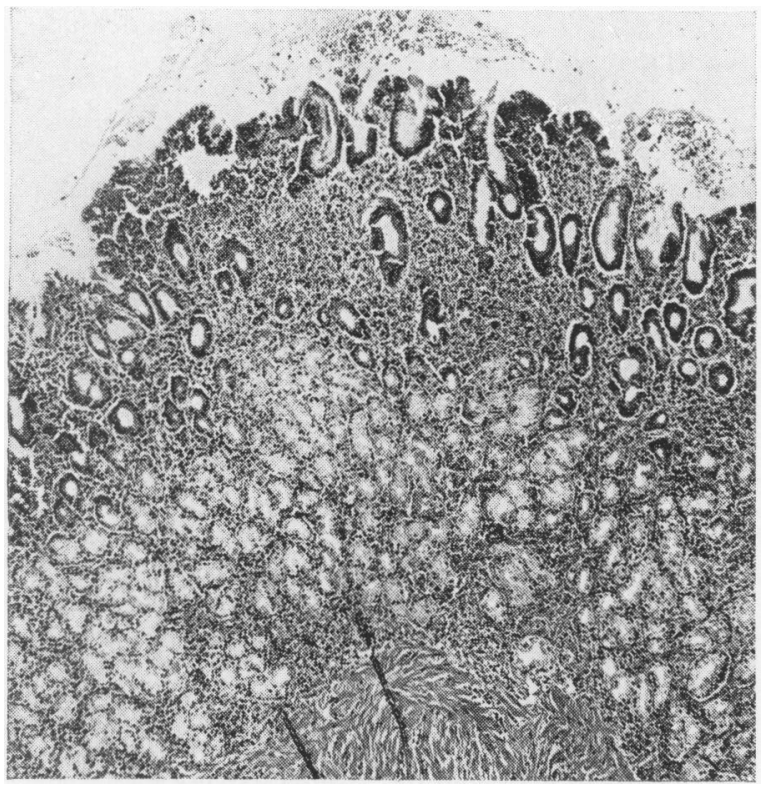

FIG. 2 .

Fifteen male patients were anaemic $(\mathrm{Hb}<13.5$ $\mathrm{g} \%)$ and 11 female patients $(\mathrm{Hb}<11.5 \mathrm{~g} \%)$. In general, however, patients who were anaemic postoperatively had been anaemic preoperatively, or had a convincing reason for anaemia not directly related to the operation itself. This factor was considered more fully in those patients admitted for hospital investigations.

EFFECT OF OPERATION ON WEIGHT The majority of

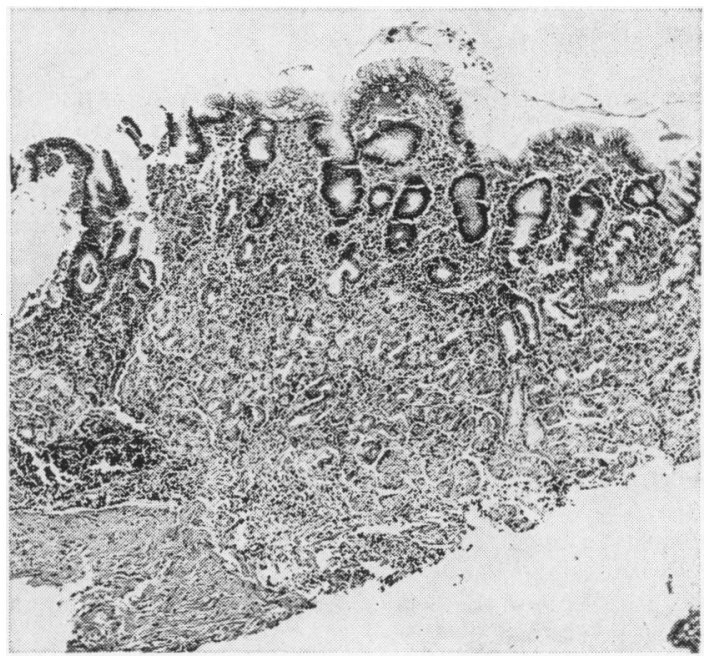

FIG. 3.

FIG. 1. Gastritic change, grade I. There is some degree of lymphocytic and plasma cell infiltration but little reduction in total thickness of the mucosa and minimal loss of specialized epithelial cells from the glands. Mucosal thickness is measured from the superficial edge of the muscularis mucosae to the free margin of the epithelium. (Haematoxylin and eosin $\times 50$.)

FIG. 2. Gastritic change, grade II. Considerable loss of specialized epithelial cells is evident in the deeper parts of the glands which are pale-staining due to replacement by mucus-secreting cells. The mucosa is moderately reduced in thickness and chronic inflammatory infiltration is more marked than in grade I (Haematoxylin and eosin $\times 50$.)

FIG. 3. Gastritic change, grade III. The mucosa is considerably reduced in thickness, there is almost complete loss of specialized epithelial cells and chronic inflammatory infiltration is a conspicuous feature (Haematoxyline and eosin $\times 50$.)

patients remained at the same weight or gained weight postoperatively (Table V). Weight gain was most marked in those patients who were underweight at the time of surgery, and whose weight loss before surgery had been relatively rapid.

Thus 108 of the 136 patients on whom information was available either gained weight or maintained their preoperative weight. Of the 28 patients who lost weight, six were obese preoperatively, and had voluntarily reduced their weight, and five patients 
TABLE IV

EFFECT OF OPERATION ON HAEMOGLOBIN LEVEL

\begin{tabular}{|c|c|c|c|c|c|}
\hline \multirow[t]{2}{*}{$\operatorname{Sex}$} & \multirow{2}{*}{$\begin{array}{l}\text { No. of } \\
\text { Patients }\end{array}$} & \multirow{2}{*}{$\begin{array}{l}\text { Mean Age } \\
\text { of Patients } \\
(y r)\end{array}$} & \multicolumn{2}{|c|}{ Haemoglobin Level $(\mathrm{g} / 100 \mathrm{ml})$} & \multirow{2}{*}{$\begin{array}{l}\text { Significant } \\
\text {-Change }\end{array}$} \\
\hline & & & Preoperative & Postoperative & \\
\hline $\begin{array}{l}\text { Male } \\
\text { Female }\end{array}$ & $\begin{array}{l}55 \\
40\end{array}$ & $\begin{array}{l}50 \\
49\end{array}$ & $\begin{array}{l}13 \cdot 7 \pm 1 \cdot 22 \\
12 \cdot 0 \pm 1 \cdot 71\end{array}$ & $\begin{array}{l}13.76 \pm 1 \cdot 13 \\
11.9 \pm 2.0\end{array}$ & $\begin{array}{l}\text { No } \\
\text { No }\end{array}$ \\
\hline
\end{tabular}

TABLE V

EFFECT OF OPERATION ON WEIGHT

\begin{tabular}{ll} 
Weight Change & $\begin{array}{l}\text { No. of } \\
\text { Patients }\end{array}$ \\
\hline Stationary & 55 \\
Gain $(>5 \mathrm{lb})$ & 53 \\
Loss $(>5 \mathrm{lb})$ & 28 \\
Undetermined & 15
\end{tabular}

were suffering from other medical conditions or had suffered unrelated severe illness since operation (pulmonary tuberculosis (two), chronic renal disease (one), disabling chronic bronchitis and asthma (one), and pneumonia with empyema thoracis (one)). In the remaining 17 patients the weight loss was attributed to the operation, or to its sequelae.
RESULTS OF INVESTIGATIONS ON 35 PATIENTS ADMITTED TO HOSPITAL

In this group of patients there were six anaemic females and two anaemic males. The results in the non-anaemic patients are summarized in Table VI, and those in the anaemic patients in Table VII. Though in two patients (nos. 29 and 34, Table VII) evidence of deficiency of iron, vitamin $B_{12}$, or of folic acid was not evident, in the first the blood urea was raised to $70 \mathrm{mg}$ per $100 \mathrm{ml}$. All the other anaemic patients were deficient in iron and in addition four other non-anaemic patients were also iron deficient. As is seen in Table VIII eight of the 10 patients with iron deficiency had evidence of blood loss before surgery though none was actually

TABLE VI

RESULTS OF METABOLIC STUDIES IN NON-ANAEMIC PATIENTS

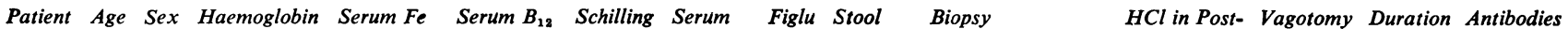

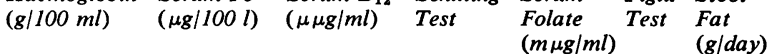

\begin{tabular}{|c|c|c|}
\hline Biopsy & & $\mathrm{HCl}$ in Post- \\
\hline $\begin{array}{l}\text { Gastric } \\
\text { (Grade) }\end{array}$ & Jejunal & $\begin{array}{l}\text { Hour } \\
\text { (m-equiv/hr) }\end{array}$ \\
\hline
\end{tabular}
of Follow to Parietal Up (yr) Cells and Intrinsic Factor

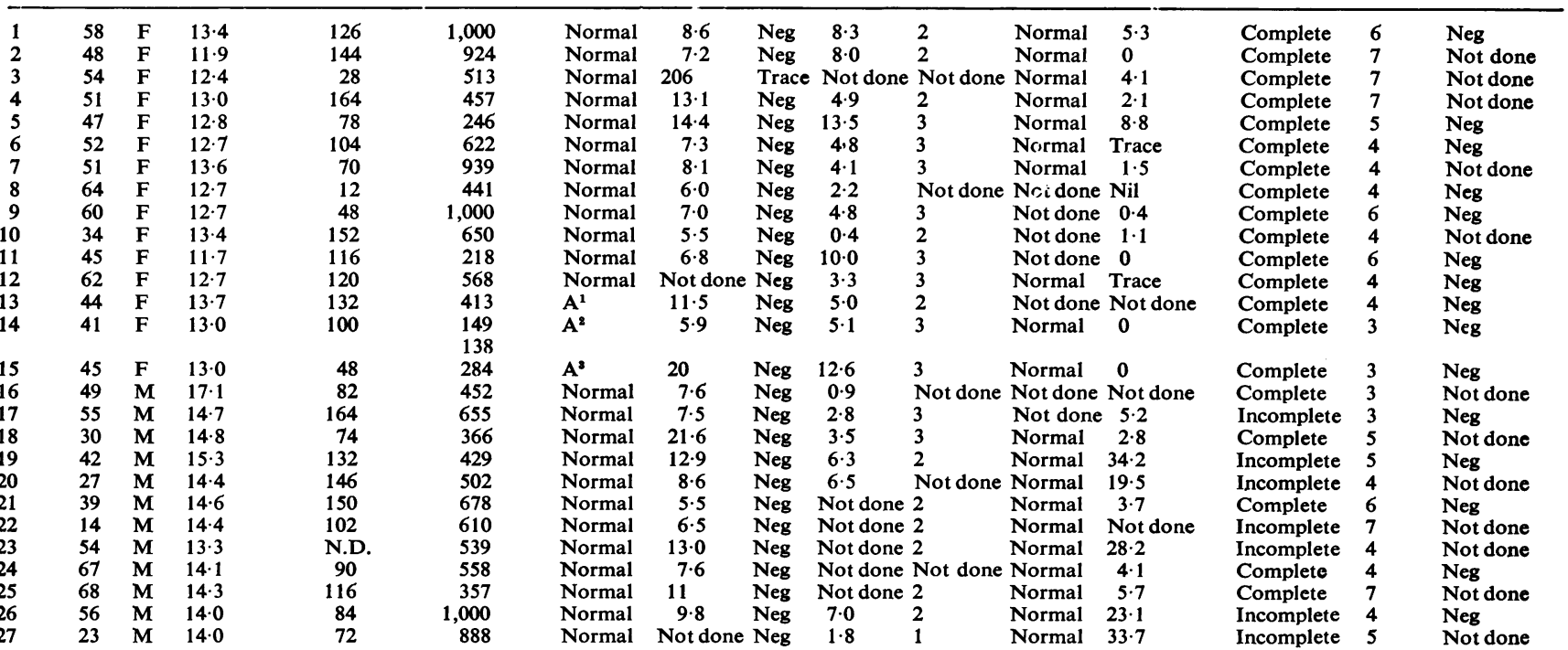

$16.6 \%$ recovery.

$27.1 \%$ and $8.4 \%$ recovery. After antibiotics $9.3 \%$ recovery. With intrinsic factor 12.5 and $16.5 \%$ recovery. $20.1 \%$ recovery. 
TABLE VII

RESULTS OF METABOLIC STUDIES IN ANAEMIC PATIENTS

\begin{tabular}{|c|c|c|c|c|c|c|c|c|c|c|c|c|c|c|c|}
\hline \multirow[t]{2}{*}{ Patient } & \multirow[t]{2}{*}{ Age } & \multirow[t]{2}{*}{ Sex } & \multirow{2}{*}{$\begin{array}{l}\text { Haemoglobin } \\
(\mathrm{g} / 100 \mathrm{ml})\end{array}$} & \multirow{2}{*}{$\begin{array}{l}\text { Serum Fe } \\
(\mu \mathrm{g} / 100 \mathrm{ml})\end{array}$} & \multirow{2}{*}{$\begin{array}{l}\text { Serum } B_{12} \\
(\mu \mu g / m l)\end{array}$} & \multirow{2}{*}{$\begin{array}{l}\text { Schilling } \\
\text { Test }\end{array}$} & \multirow{2}{*}{$\begin{array}{l}\text { Serum } \\
\text { Folate } \\
(m \mu g \mid m l)\end{array}$} & \multirow{2}{*}{$\begin{array}{l}\text { Figlu } \\
\text { Test }\end{array}$} & \multirow{2}{*}{$\begin{array}{l}\text { Stool Fat } \\
\text { (g/day) }\end{array}$} & \multicolumn{2}{|l|}{ Biopsy } & \multirow{2}{*}{$\begin{array}{l}\text { HCl in Post- } \\
\text {-histamine } \\
\text { Hour } \\
\text { (m-equiv/hr) }\end{array}$} & \multirow[t]{2}{*}{ Vagotomy } & \multirow{2}{*}{$\begin{array}{l}\text { Duration } \\
\text { of Follow } \\
U p(y r)\end{array}$} & \multirow{2}{*}{$\begin{array}{l}\text { Antibodies } \\
\text { to Parietat } \\
\text { Cells and } \\
\text { Intrinsic } \\
\text { Factor }\end{array}$} \\
\hline & & & & & & & & & & $\begin{array}{l}\text { Gastric } \\
\text { (Grade) }\end{array}$ & Jejunal & & & & \\
\hline 28 & 61 & $\mathbf{F}$ & $10 \cdot 4$ & 54 & 333 & Normal & 11.9 & Trace & $17 \cdot 6$ & 3 & Normal & $\mathbf{0}$ & Complete & 9 & Neg \\
\hline 29 & 67 & $\mathbf{F}$ & $11 \cdot 1$ & 110 & 197 & Normal & 9.4 & $\mathrm{Neg}$ & 6.8 & Not done & Not done & $\mathbf{0}$ & Complete & 6 & Neg \\
\hline 30 & 41 & $\mathbf{F}$ & $10 \cdot 1$ & 38 & 373 & Normal & Not done & Neg & $5 \cdot 7$ & 2 & Normal & $9 \cdot 3$ & Incomplete & 5 & Neg \\
\hline 31 & 49 & $\mathbf{F}$ & $7 \cdot 4$ & 16 & 492 & $\mathbf{A}^{1}$ & $12 \cdot 3$ & Neg & $4 \cdot 0$ & Not done & Not done & 0 & Complete & 6 & Neg \\
\hline 32 & 30 & $\mathbf{F}$ & $8 \cdot 3$ & 24 & 375 & Normal & $5 \cdot 4$ & Neg & $4 \cdot 1$ & Not done & Normal & Trace & Complete & 2 & Not dor \\
\hline 33 & 59 & $\mathbf{F}$ & $7 \cdot 0$ & 12 & 131 & $\mathbf{A}^{2}$ & $13 \cdot 5$ & Pos & $2 \cdot 5$ & 3 & Not done & 0 & Complete & 5 & $\mathrm{Neg}$ \\
\hline 34 & 59 & $\mathbf{M}$ & $13 \cdot 0$ & 98 & 278 & Normal & $12 \cdot 2$ & Neg & $17 \cdot 4$ & Not done & Normal & $1 \cdot 2$ & Complete & 3 & Neg \\
\hline 35 & 65 & $\mathbf{M}$ & $7 \cdot 0$ & 16 & 223 & Normal & 18.0 & $\mathrm{Neg}$ & $2 \cdot 4$ & Not done & Not done & Trace & Complete & 3 & $\mathrm{Neg}$ \\
\hline
\end{tabular}

$13.4 \%$ recovery.

$25.6 \%$ recovery; with intrinsic factor $19.0 \%$ recovery.

TABLE VIII

OPERATIVE CONDITION OF PATIENTS WITH IRON DEFICIENCY (WITH AND WITHOUT ANAEMIA) AT THE TIME OF REVIEW

\begin{tabular}{lll} 
Patient & Sex & $\begin{array}{c}\text { Haemoglobin } \\
(\mathrm{g} / 100 \mathrm{ml})\end{array}$ \\
\hline 3 & F & Not done \\
8 & F & 12.7 \\
9 & F & 13.9 \\
15 & F & 14.6 \\
28 & F & Not done \\
30 & F & $6 \cdot 5$ \\
31 & F & 10.2 \\
32 & F & 11.7 \\
33 & F & $9 \cdot 3$ \\
35 & M & Not done
\end{tabular}

Operative Condition

Operation following haematemesis and melaena. Required transfusion

Very underweight at time of surgery $(35.5 \mathrm{~kg})$

Haematemesis five months before surgery

Dyspepsia

Haematemesis and melaena requiring blood transfusion before surgery

Operation after haematemesis and melaena

Pyloric stenosis

Melaena a few weeks before surgery. Heavy menstrual loss both before and after surgery

Haematemesis and melaena three months and one week before surgery

Melaena in week before surgery

TABLE IX

RELATIONSHIP OF ACID SECRETION TO HISTOLOGICAL APPEARANCE OF GASTRIC MUCOSA

\begin{tabular}{|c|c|c|c|c|c|}
\hline \multirow[t]{2}{*}{ Histology } & \multirow{2}{*}{$\begin{array}{l}\text { No. of } \\
\text { Patients }\end{array}$} & \multirow{2}{*}{$\begin{array}{l}\text { Mean Secretion } \\
\text { (HCl/m-equiv) }\end{array}$} & \multirow{2}{*}{$\begin{array}{l}\text { Mean Follow Up } \\
(y r)\end{array}$} & \multicolumn{2}{|c|}{ Vagotomy Status } \\
\hline & & & & Complete & Incomplete \\
\hline I & 1 & $33 \cdot 7$ & 5 & - & 1 \\
\hline II & 12 & $\begin{array}{l}12 \cdot 5^{1} \\
\text { (Range 0-34.2) }\end{array}$ & $5 \cdot 5$ & 7 & 5 \\
\hline III & 12 & $\begin{array}{l}1 \cdot 5^{1} \\
\text { (Range 0-8.8) }\end{array}$ & $4 \cdot 5$ & 11 & 1 \\
\hline
\end{tabular}

${ }^{1}$ Though the difference in secretion between subjects in histological grades II and III is highly significant $(\mathrm{t}=5 \cdot 2, \mathrm{P}<0.001)$, this significance disappears if the state of the vagotomy is taken into account.

bleeding at the time of operation. A similar analysis of the findings in the 23 patients without anaemia or iron deficiency at the time of review showed that seven had in fact been mildly anaemic at the time of surgery. In none of the patients who were anaemic or iron deficient at the time of review was there detectable occult blood loss in the faeces or a demonstrable source of gastrointestinal bleeding.

Two patients had low serum levels of vitamin $\mathbf{B}_{12}$ and five had impaired absorption of the vitamin. Sternal marrow examination in patient no. 14, (Table VI) was normoblastic. Antibodies to parietal cells or to intrinsic factor were not found in any of the patients in whom they were assayed. In all the patients the serum folate levels were normal but in one (no. 33, Table VII) the Figlu test was strongly positive. The significance of these findings is discussed later.

All the jejunal biopsies which were performed were normal. In the gastric biopsies, however, severe changes were seen in 12 patients, though in no instance were the extreme changes of complete gastric atrophy evident. An attempt was made without success to relate the histological features of the gastric mucosa to the presence or absence of anaemia and to the maximal acid output. Patients with more severe gastritis (grade III) had a significantly lower maximal acid output than those 
patients with grade I or II gastritis (Table IX), but, if only patients with a complete surgical vagotomy were compared, there was no significant difference in secretion between group II and group III patients.

Eight patients had steatorrhoea but in none was there any biochemical evidence of osteomalacia.

\section{DISCUSSION}

The low mortality of truncal vagotomy and gastroenterostomy confers an immediate advantage on this procedure when compared with partial gastrectomy. Elective partial gastrectomy in the same surgical unit during the same period carried an operative mortality rate of $4.4 \%$ (Macleod, 1967).

This advantage has not in our hands been vitiated by an increased stomal ulcer rate, and it is probable that the stomal ulcer rate (and the incidence of residual dyspepsia without proven stomal ulcer) can be reduced. All the patients in this series with proven stomal ulcer were shown by the insulin test to have had an incomplete vagotomy. Though stomal ulcer may result from other causes (Small, 1964; Giles and Clark, 1966), incomplete vagotomy is a most important, if not the most important, aetiological factor.

In those patients who have residual ulcer-type dyspepsia, but without proven stomal ulceration, incomplete vagotomy also appears to play a part. Eight of the 15 patients with residual dyspepsia have undergone insulin tests, which demonstrated that an incomplete vagotomy had been performed in six. The relationship of continuing ulcer-type dyspepsia to stomal ulceration is unclear, but it may well be that some of these patients do have stomal ulcers which we have failed to demonstrate.

Though a higher rate of complete vagotomy will reduce the incidence of stomal ulceration, and possibly residual ulcer dyspepsia, the incidence of other sequelae of gastroenterostomy and vagotomy in this series is disturbingly high, and emphasis must also be placed on these sequelae when considering ways and means of improving surgical results.

Diarrhoea is a familiar and unpleasant complication of vagotomy. In a severe form it occurred in $5 \%$ of our patients, but in those patients less severely affected, this complication was an acceptable exchange for their previous ulcer dyspepsia. The direct cause of the diarrhoea is uncertain, but the vagotomy itself must be implicated in view of the lower incidence of diarrhoea in patients undergoing gastric surgery without vagotomy (Clark, 1961; Marshall, 1964; Goligher, Pulvertaft, and Franz, 1966).

Bilious vomiting occurred to greater or lesser degree in $23 \%$ of our patients. In six patients it was a handicap, three requiring conversion to pyloroplasty to cure the condition. The use of pyloroplasty as an alternative to gastroenterostomy for the drainage procedure may reduce this complication in a severe form by avoiding the presence of an afferent loop, though in our hands (Macleod, 1967) the overall incidence of vomiting after pyloroplasty is similar to that after gastroenterostomy and the risk of recurrent ulceration is greater.

The incidence of dumping in this series is high $(40 \%)$, and is difficult to compare directly with other series in the literature because of wide variations in criteria utilized to define this condition. Our criteria for dumping are strict in that inability to eat a normal sized meal without epigastric discomfort and fullness is regarded as mild dumping. Forty-one of the 56 patients fell into this category, and the majority of these patients have learned to avoid symptoms by eating smaller than normal meals. Though they are symptom-free as a result of their adapted eating habits, we feel that they should be included as 'dumpers' in any realistic consideration of the full effects of gastric surgery. Fifteen patients $(10.7 \%)$ had more severe dumping, had a relatively poor response to medical treatment, and have shown little tendency to improve with the passage of time.

The effect of the operation on overall nutritional status in this series was good. Only 17 patients showed a weight loss which could be attributed to the operation. This finding is similar to the results reported by Small, Falconer, Smith, and Bruce (1967). Though Small and his colleagues found no great difference in weight behaviour in patients having partial gastrectomy or vagotomy and gastroenterostomy, most reports (Cox et al, 1964; Goligher et al, 1966) suggest that the partial gastrectomy patients do lose weight more frequently.

\section{METABOLIC STUDIES}

There is now much knowledge of the nutritional status of patients who have undergone partial gastrectomy (Glaxo Symposium, 1966). The most complete study in patients after gastroenterostomy with vagotomy is that of Cox and his colleagues (1964). Using similar criteria, the incidence of anaemia in their series $(26 \%$ in females and $8 \%$ in males) is similar to our own. They also emphasized the higher incidence of anaemia or bleeding at the time of surgery in those patients found to be anaemic at the time of follow up. This has also been mentioned recently in patients who have undergone partial gastrectomy (Callender, 1967). However, these observations do not exclude the possibility that the incidence of iron-deficiency anaemia after 
gastroenterostomy and vagotomy may increase with longer follow up.

Studies of vitamin $\mathbf{B}_{\mathbf{1 2}}$ metabolism after gastric surgery are at present bedevilled by difficulties in the interpretation of results. Serum vitamin $B_{12}$ levels may be depressed in the presence of iron deficiency (Cox, Meynell, Gaddie, and Cooke, 1959; Mollin, Waters, and Harriss, 1962) and moderately depressed levels do not necessarily indicate tissue depletion of vitamin $B_{12}$ (Mollin et al, 1962). Similarly the Schilling test may be unreliable (Adams and Cartwright, 1963). Consequently, the results in patients nos. 13, 14, 15 (Table VI) and no. 31 (Table VII), though suggestive of a developing deficiency of vitamin $B_{12}$, must be interpreted with caution. We feel, however, that the results in patient no. 33 (Table VII) indicate deficiency of vitamin $B_{12}$ as well as of iron. Abnormal urinary excretion of Figlu is recognized in anaemia due to deficiency of vitamin $B_{12}$ but is not likely to occur in such large amounts in association with iron deficiency only (Kohn et al, 1961; Kershaw and Girdwood, 1964). Cox and his colleagues (1964) had one patient with a serum vitamin $B_{12}$ level of less than $150 \mu \mu \mathrm{g}$ per ml but their incidence of impaired absorption of the vitamin was similar to our own.

In none of our patients was there evidence of folic acid deficiency, and it is probable that this will be an unusual complication after gastroenterostomy and vagotomy. It is said to occur in $1 \%$ of patients following partial gastrectomy (Glaxo Symposium, 1966).

None of the patients had complete gastric atrophy at the time of review. However, there was a high incidence of severe changes in the gastric biopsies, though this must be interpreted in the light of the known high incidence of abnormality in non-ulcer patients with increasing age (Joske, Finckh, and Wood, 1955). There were insufficient numbers of operative gastric biopsies with which to compare the findings at the time of review, though in two patients with grade III changes at review (including patient no. 14, Table VI), the mucosa was normal at the time of surgery. On the whole, however, the results are similar to those of Melrose, Russell, and Dick (1964) and do not provide conclusive evidence that vagotomy causes gastric atrophy. As far as the jejunal biopsies are concerned the normal findings would support our previous observations that an abnormal biopsy cannot be interpreted as resulting from gastric surgery (Girdwood et al, 1966).

Eight patients had steatorrhoea and one of these (patient no. 34, Table VII) has since developed impaired vitamin $B_{12}$ absorption which is markedly improved by giving antibiotics but not intrinsic factor. Steatorrhoea is a well recognized complication of gastroenterostomy and vagotomy though our own incidence of this is slightly lower than that of Cox and his colleagues (1964). The causes of steatorrhoea in these patients are likely to be multiple and have been discussed elsewhere (Dellipiani and Girdwood, 1967).

\section{ALTERNATIVE PROCEDURES}

In the light of these results it is worth considering alternative surgical procedures for the management of chronic duodenal ulcer. Vagotomy may be unnecessary in a proportion of duodenal ulcer patients. Though the operation of gastroenterostomy without vagotomy was largely discredited because of reported recurrent ulceration rates of 30 to $50 \%$ (if the follow up be long enough) it also follows that the remaining 70 to $50 \%$ were cured by the operation. The problem is to select the patient who will be cured. Small and his colleagues (Small, 1964) noted that they have not had a jejunal ulcer develop following gastroenterostomy alone in patients whose gastric acid secretion in the hour following maximal histamine stimulization is less than $30 \mathrm{HCl}$ (m-equiv/ hr). Our own experience is similar, and we are now employing the operation in such patients. The lower incidence of diarrhoea (Marshall, 1964), and the great sense of well being following gastroenterostomy (Small, 1964) vindicates greater use of this operation. A further point to weigh in this connexion is the possibility that incomplete vagotomy may in some patients carry a higher risk of recurrent ulceration than drainage with no vagotomy at all: for though no patient with stomal ulcer following gastroenterostomy alone has had an acid secretion of less than $30 \mathrm{HCl}$ (m-equiv/hr) in the post-histamine hour, this is not the case in our patients with jejunal ulcer following gastroenterostomy and vagotomy. The lowest residual (post-vagotomy) secretion in the latter group was $17 \mathrm{HCl}$ (m-equiv/hr), and the lowest pre-vagotomy secretion was $22 \mathrm{HCl}$ (m-equiv/ hr) in the post-histamine hour. The reason for this finding is obscure, but preferential interference with the inhibitory or protective mechanism in the duodenum is a possible explanation (Johnston, Goligher, and Duthie, 1966).

In those patients in whom vagotomy is considered necessary, it must be made complete. However, it is well known that by subdiaphragmatic truncal vagotomy it is difficult to achieve this aim, though the reported incidence of incomplete vagotomy varies widely (McKelvie, 1963; Ross and Kay, 1964; Holt and Lythgoe, 1965). In our hands the incidence of incomplete vagotomy is $35 \%$ (Macleod, 1967), and despite more assiduous surgical technique resulting from an awareness of this figure, this 
incidence has not been reduced during the past 12 months. Harkins, Stavney, Griffith, Savage, Kato, and Nyhus (1963) and Burge (1964) have claimed that selective gastric vagotomy improves the likelihood of complete surgical vagotomy, and further, that by preserving hepatobiliary and intestinal vagal innervation, the incidence of postvagotomy diarrhoea is decreased. Not all would agree with such claims (Brit. med. J., 1968), and controlled clinical trials of selective vagotomy are indicated to assess these points.

Johnston, Goligher, and Duthie (1966) have claimed that complete vagotomy will prevent jejunal ulceration regardless of the initial acid secretion, and our experience supports this. However, in patients with an initial high acid secretion, an incidence of incomplete vagotomy of $35 \%$ would expose too many of these patients to a high risk of jejunal ulceration. In such patients, the insurance of additional antrectomy appears justifiable, as the incidence of stomal ulceration following vagotomy and antrectomy is very low (Herrington, Edwards, Classen, Carlson, Edwards, and Scott, 1959). In most hands, it carries a higher mortality rate than vagotomy with a drainage procedure, and therefore cannot be recommended for routine use. The longterm metabolic effects of antrectomy with vagotomy are little known, though Dean, Edwards, and Munro (1966) have demonstrated histamine-fast achlorhydria in all of 13 patients tested 10 or more years after operation.

\section{SUMMARY AND CONCLUSION}

The clinical and metabolic results of vagotomy and gastroenterostomy in a series of patients treated for chronic duodenal ulcer are presented. In our hands, the operation has been associated with a disturbingly high incidence of undesirable sequelae. From the point of view of late metabolic complications the findings confirm those of Cox et al (1964) because, even after a relatively short period of follow up, metabolic derangements are apparent. Weight loss after gastroenterostomy and vagotomy is, however, less frequent than after partial gastrectomy, suggesting that the overall nutritional status of the vagotomy patients is likely to be better.

It is recommended that a policy of selective surgery be followed when managing patients with chronic duodenal ulcer. In general terms, the lesser gastric procedures are followed by less serious metabolic side effects, and, provided the risk of stomal ulceration is kept at a minimum by suitable selection of patients, the overall results of surgery might be improved. We are at present in the process of assessing such a selective policy based on preoperative maximal gastric secretion stimulated by Pentagastrin (ICI 50123): (1) Patients with secretion of $<30 \mathrm{HCl}$ (m-equiv/hr) in the hour after stimulation are offered gastroenterostomy alone. (2) Patients with secretion of 30 to $50 \mathrm{HCl}$ (m-equiv/hr) are offered vagotomy in association with a drainage procedure. (3) Patients with secretion of $>50 \mathrm{HCl}$ (m-equiv/hr) are offered antrectomy and vagotomy.

One of the authors, Mr I. B. Macleod, was in receipt of a Medical Research Council scientific fellowship during the course of this work, and wishes to thank the Council for their support.

The authors wish to thank Professor Sir John Bruce and Professor R. H. Girdwood for the opportunity to study patients under their care.

We are also most grateful to Dr W. J. Irvine who carried out the intrinsic factor determinations.

\section{REFERENCES}

Adams, J. F., and Cartwright, E. J. (1963). The reliability and reproducibility of the Schilling test in primary malabsorptive disease and after partial gastrectomy. Gut, 4, 32-36.

Bank, S., Marks, I. N., and Louw, J. H. (1967). Histamine- and insulin-stimulated gastric acid secretion after selective and truncal vagotomy. Ibid., 8, 36-41.

British Medical Journal (1968). Leader. Vagotomy in treatment of duodenal ulcer. Brit. med. J., 1, 461-462.

Burge, H. (1964). Vagotomy. Arnold, London.

Callender, S. T. (1967). Post-gastrectomy Nutrition, 1966. (Glaxo Symposium), edited by D. M. Krikler, p. 62. Lloyd-Luke, London.

Clark, C. G. (1961). Vagotomy for peptic ulcer. Brit. med. J., 1, 1250-1251.

Cox, A. G., and Bond, M. R. (1964). Bowel habit after vagotomy and gastrojejunostomy. Ibid., 1, 460-465.

- , Podmore, D. A., and Rose, D. P. (1964). Aspects of nutrition after vagotomy and gastro-jejunostomy. Ibid., 1, 465-469.

Cox, E. V., Meynell, M. J., Gaddie, R., and Cooke, W. T. (1959). Inter-relation of vitamin $B_{12}$ and iron. Lancet, 2, 998-1001.

Crosby, W. H., and Kugler, H. W. (1957). Intraluminal biopsy of the small intestine: the intestinal biopsy capsule. Amer. J. dig. Dis., 2, 236-241.

Dacie, J. V., and Lewis, S. M. (1963). Practical Haematology, 3rd ed. Churchill, London.

Dean, A. C. B., Edwards, H. C., and Munro, A. I. (1966). Late results of antrectomy and vagotomy. Gut, 7, 677-679.

Dellipiani, A. W., and Girdwood, R. H. (1967). The significance of abnormal bacterial proliferation in the gastrointestinal tract after gast ric surgery. Scand.J. Gastroent., 2, 161-168.

Doig, A., and Girdwood, R. H. (1960). The absorption of folic acid and labelled cyanocobolamin in intestinal malabsorption, with observations on the faecal excretion of fat and nitrogen and the absorption of glucose and xylose. Quart. J. Med., 29, 333-374.

Dragstedt, L. R., and Owens, F. M., Jr (1943). Supra-diaphragmatic section of the vagus nerves in treatment of duodenal ulcer. Proc. Soc. exp. Biol. (N.Y.), 53, 152-154.

Giles, G. R., and Clark, C. G. (1966). Gastric secretion stimulated by meat extraction in man: a test of antral function. Scand. J. Gastroent., 1, 159-166.

Girdwood, R. H. (1956). The megaloblastic anaemias. Quart. J. Med., 25, 87-119.

_ (1960). Microbiological methods of assay in clinical medicine with particular reference to the investigation of deficiency of vitamin $B_{12}$ and folic acid. Scot. med.J., 5, 10-22.

—, Williams, A. W., McManus, J. P. A., Dellipiani, A. W., Delamore, I. W., and Kershaw, P. W. (1966). Jejunal biopsy in patients with malabsorptive disease. Scot. med. J., 11, 343-355.

Glaxo Symposium (1967). Post-gastrectomy Nutrition, 1966, edited by D. M. Krikler, Lloyd-Luke, London. 
Goligher, J. C., Pulvertaft, C. N., and Franz, R. C. (1966). A comparison of surgical methods in the treatment of duodenal ulcer. In Postgraduate Gastroenterology: the Proceedings of a Conference, Glasgow, 1965, edited by T. J. Thomson and I. E. Gillespie, pp. 246-259. Ballière, Tindall, and Cassel, London.

Harkins, H. N., Stavney, L. S., Griffith, C. A., Savage, L. E., Kato, T., and Nyhus, L. M. (1963). Selective gastric vagotomy. Ann. Surg. 158, 448-460.

Herrington, J. L., Jr, Edwards, L. W., Classen, K. L., Carlson, R. I., Edwards, W. H., and Scott, H. W., Jr (1959). Vagotomy and antral resection in the treatment of duodenal ulcer. Ibid., 150, 499-516.

Hollander, F. (1946). The insulin test for the presence of intact nerve fibres after vagal operations for peptic ulcer. Gastroenterology, 7, 607-614.

Holt, R. L., and Lythgoe, J. P. (1965). The treatment of chronic duodenal ulcer by vagotomy and anterior pylorectomy. Brit. J. Surg., 52, 27-32.

Irvine, W. J. (1966). Immunoassay of gastric intrinsic factor and the titration of antibody to intrinsic factor. Clin. exp. Immunol., 1, 99-118.

Johnston, D., Goligher, J. C., and Duthie, H. L. (1966). Medical vagotomy: an assessment. Brit. med.J., 2, 1481-1485.

Joske, R. A., Finckh, E. S., and Wood, I. J., (1955). Gastric biopsy: a study of 1,000 consecutive successful gastric biopsies. Quart. J. Med., 24, 269-294.

Kamer, J. H. van de, Huinink, H. ten Bokkel, and Weyers, H. A. (1949). Rapid method for the determination of fat in feces. J. biol. Chem., 177, 347-355.

Kay, A. W. (1953). Effect of large doses of histamine on gastric secretion of $\mathrm{HCl}$ : an augmented histamine test. Brit. med. J., 2, 77-80.
Kershaw, P. W., and Girdwood, R. H. (1964). Some investigations of folic acid deficiency. Scot. med.J., 9, 201-212.

Kohn, J., Mollin, D. L., and Rosenbach, L. M. (1961). Conventional voltage electrophoresis for formiminoglutamic-acid determination in folic acid deficiency. J. clin. Path., 14, 345-350.

MacKelvie, A. A. (1963). Treatment of stomal ulcer. Lancet, 1, 1073.

Macleod, I. B. (1967). Duodenal ulcer: the surgeon's dilemma. J. roy. Coll. Surg. Edinb., 12, 285-307.

Marshall, R. L. (1964). Diarrhoea following gastric surgery-with particular reference to diarrhoea following vagotomy. Ibid., 9, 307-310.

Melrose, A. G., Russell, R. I., and Dick, A. (1964). Gastric mucosal structure and function after vagotomy. Gut, 5, 546-549.

Mollin, D. L., Waters, A. H., and Harriss, E. (1962). Clinical aspects of the metabolic interrelationships between folic acid and vitamin $B_{12}$. In Vitamin $B_{12}$ and Intrinsic Factor: 2, Europäisches Symposion, Hamburg, edited by H. C. Heinrich, pp. 737-755, Stuttgart.

Ramsay, W. N. M. (1953). The determination of iron in blood, plasma or serum. Biochem.J., 53, 227-231.

Ross, B., and Kay, A. W. (1964). The insulin test after vagotomy. Gastroenterology, 46, 379-386.

Schilling, R. F. (1953). Intrinsic factor studies II. The effect of gastric juice on the urinary excretion of radioactivity after the oral administration of radioactive vitamin $\mathbf{B}_{12}$. J. Lab. clin. Med., 42, 860-866.

Small, W. P. (1964). The recurrence of ulceration after surgery for duodenal ulcer. J. roy. Coll. Surg. Edinb., 9, 255-278.

_-, Falconer, C. W. A., Smith, A. N., and Bruce, J. (1967). Weight behaviour after operation for duodenal ulcer. Ibid., 12, 133-138. 